\title{
ANALISIS PEMAHAMAN KONSEP FISIKA PESERTA DIDIK KELAS $X$ IPA DI SMA NEGERI 1 MANOKWARI MELALUI PEMBELAJARAN ONLINE
}

\author{
Dian Novitasari ${ }^{1}$, Sri Wahyu Widyaningsih ${ }^{2}$, Sri Rosepda Br. Sebayang ${ }^{3}$ \\ adiannovita22@gmail.com \\ ${ }^{1,2,3}$ Program Studi Pendidikan Fisika, Universitas Papua, Provinsi Papua Barat, Indonesia
}

Received: 28 Mei $2021 \quad$ Revised: 29 Mei $2021 \quad$ Accepted: 15 Juni 2021

\begin{abstract}
This study aims to analyze student's understanding of the physical concepts in class X IPA SMA Negeri 1 Manokwari through the online learning. The research method used is a survey method using a test instrument. The sampling technique used was purposive sampling with the test sample was 66 students from the first 2 classes who completed the material and the research sample was 219 students from the other 7 classes. The instrument used in this study was a test of understanding the concept of physics which was made and arranged by paying attention to the cognitive process of understanding the concept which consisted of 17 valid questions. The results of the analysis showed that the student's ability to understand the physics concepts of class X IPA at SMA Negeri 1 Manokwari on Newton's law material about straight motion were divided into five categories. The very high category was $4 \%$, the high category was $20 \%$, the moderate category was $39 \%$, the low category was $25 \%$ and the very low category was $12 \%$. The most visible understanding of the physics concepts is the cognitive process of interpreting with a percentage of very high and high ability students of $57,1 \%$.
\end{abstract}

Abstrack: Concept Understanding, Physics, Online Learning

Abstrak: Penelitian ini bertujuan untuk menganalisis pemahaman konsep fisika peserta didik kelas $X$ IPA SMA Negeri 1 Manokwari melalui pembelajaran online. Metode penelitian yang digunakan adalah metode survey dengan menggunakan instrumen berupa tes. Teknik penentuan sampel yang digunakan adalah purposive sampling dengan sampel uji coba instrumen sebanyak 66 peserta didik dari 2 kelas yang pertama menyelesaikan materi dan sampel penelitian sebanyak 219 peserta didik dari 7 kelas lainnya. Instrumen yang digunakan dalam penelitian ini berupa tes pemahaman konsep fisika yang dibuat dan disusun dengan memperhatikan proses kognitif pemahaman konsep yang terdiri dari 17 pertanyaan yang sudah valid. Hasil analisis menunjukkan kemampuan pemahaman konsep fisika peserta didik kelas X IPA di SMA Negeri 1 Manokwari pada materi hukum Newton tentang gerak lurus tersebar ke dalam lima kategori. Kategori sangat tinggi sebanyak 4\%, kategori tinggi sebanyak 20\%, kategori sedang sebanyak 39\%, kategori rendah sebanyak $25 \%$ dan kategori sangat rendah sebanyak $12 \%$. Pemahaman konsep fisika yang paling terlihat adalah pada proses kognitif menafsirkan dengan persentase peserta didik berkemampuan sangat tinggi dan tinggi sebesar $57,1 \%$.

Kata kunci: Pemahaman Konsep, Fisika, Pembelajaran Online 


\section{PENDAHULUAN}

Pendidikan merupakan kebutuhan manusia yang penting karena pendidikan mempunyai tugas menghasilkan sumber daya manusia (SDM) yang berkualitas bagi pembangunan bangsa dan negara. Undang-Undang Republik Indonesia No. 20 Tahun 2003 tentang Sistem Pendidikan Nasional Bab 1 Pasal 1 menyatakan bahwa pendidikan adalah usaha sadar dan terencana untuk mewujudkan suasana belajar dan proses pembelajaran agar peserta didik secara aktif mengembangkan potensi dirinya untuk memiliki kekuatan spiritual keagamaan, pengendalian diri, kepribadian, kecerdasan, akhlak mulia, serta keterampilan yang diperlukan dirinya, masyarakat, bangsa dan negara (Depdiknas, 2003).

Pendidikan di dunia saat ini berada pada era Revolusi Industri 4.0, dimana penggunaan Teknologi Komunikasi dan Informasi (TIK) dalam bidang pendidikan dapat memberikan pengaruh yang sangat besar serta memiliki dampak yang positif terhadap prestasi belajar dan performansi peserta didik (Hermawanto, Kusairi, \& Wartono, 2013). Pendidikan pada era ini tidak akan pernah terlepas dari pemanfaatan media TIK, salah satunya adalah internet. Internet yang telah berkembang pesat memberikan berbagai keuntungan bagi dunia pendidikan dan seluruh penggunanya, seperti peserta didik yang semakin mudah mendapat bahan belajar tanpa batasan tempat, jarak, ruang dan waktu dengan sangat cepat (Yunita \& Nana, 2020).

Pendidikan di dunia pada awal tahun 2020 mengalami sebuah perubahan yang besar, dimana hal ini terjadi akibat adanya krisis kesehatan yang sedang melanda dunia yaitu pandemi Covid-19. Pandemi Covid-19 ini membuat banyak negara di dunia yang memutuskan untuk menutup sekolah-sekolah serta perguruan tinggi termasuk negara Indonesia. Organisasi Internasional Perserikatan Bangsa-Bangsa (PBB) bahkan mengungkapkan bahwa salah satu sektor yang begitu terdampak oleh pandemi ini adalah pendidikan (Purwanto et al., 2020). United Nations Educational, Scientific and Cultural Organization (UNESCO) pada tanggal 4 Maret 2020 menyarankan untuk membuka platform pendidikan guna pelaksanaan pendidikan jarak jauh yang dapat digunakan oleh guru dan sekolah untuk membatasi gangguan pendidikan dan menjangkau peserta didik dari jarak jauh (Setiawan, 2020). Saran dari UNESCO ini di sambut baik oleh Kementrian Pendidikan dan Kebudayaan Republik Indonesia dan ditindaklanjuti dengan mengeluarkan Surat Edaran Nomor 4 Tahun 2020 Tentang Pelaksanaan Kebijakan Pendidikan dalam Masa Darurat Penyebaran COVID pada tanggal 24 Maret 2020 lalu. Surat Edaran tersebut menjelaskan bahwa seluruh proses pembelajaran yang semula berlangsung secara tatap muka di sekolah 
akan dialihkan menjadi pembelajaran yang dilaksanakan dari rumah melalui pembelajaran secara daring atau pembelajaran online (Dewi, 2020). Perkembangan pada zaman sekarang ini dimana era globalisasi dan kualitas peradabannya, tidak pernah lagi difokuskan pada kekuatan sumber daya alam secara utuh melainkan sangat diperlukan manusia-manusia yang mampu mengembangkan suatu produk atau komponen yang penting dalam pelaksanaan pembelajaran (Apriyani, N., Ariani, T., \& Arini, W. (2020).

Pembelajaran online ini diterapkan disemua jenjang pendidikan. Salah satu Sekolah Menengah Atas (SMA) di Manokwari Provinsi Papua Barat yang menerapkan sistem pembelajaran online adalah SMA Negeri 1 Manokwari. Penerapan pembelajaran online ini diharapkan dapat membuat peserta didik tetap dapat melakukan pembelajaran bersama guru walaupun tidak bertatap muka di sekolah sehingga mereka bisa mendapatkan pengetahuan dari pelajarannya dengan baik dan benar. Peserta didik juga diharapkan bisa memperoleh hasil belajar yang baik, dan yang paling utama adalah pemahaman konsep mereka terhadap materi pelajaran yang dipelajari semakin membaik.

Pemahaman konsep adalah salah satu faktor kemampuan yang mempengaruhi hasil belajar peserta didik, namun belum tentu hasil belajar yang baik membuktikan bahwa peserta didik tersebut paham betul dengan konsep yang dipelajari (Tsabit, Amalia, \& Maulana, 2020). Peserta didik dapat dikatakan paham konsep apabila mereka dapat mengkonstruksi makna dari pesan-pesan pembelajaran yang disampaikan melalui pengajaran, buku sampai layar komputer, baik yang bersifat lisan, tulisan maupun grafis (Irwandani \& Rofiah, 2015). Pemahaman konsep sendiri merupakan faktor terpenting yang harus dimiliki peserta didik dalam setiap proses pembelajaran. Mengapa? Pelajaran yang dipelajari dengan pemahaman akan menjadi dasar peserta didik dalam pembentukan pengetahuan baru yang dapat digunakan dalam memecahkan masalah-masalah lain yang berkaitan dengan pelajarannya, pelajaran fisika salah satunya.

Mata pelajaran fisika sering kali dianggap sebagai pelajaran yang sulit dan membosankan untuk dipelajari oleh peserta didik. Pada proses pembelajaran fisika, guru harus dapat menjadikan peserta didik tidak sekedar hafal dan tahu mengenai konsep - konsep fisika, namun juga harus dapat menjadikan peserta didiknya memahami dan mengerti konsepkonsep tersebut, serta menghubungkan keterkaitannya dengan konsep lain (Azizah, Z., Taqwa, M. R. A., \& Assalam, I. T, 2020). Fisika juga merupakan salah satu pelajaran yang sangat memerlukan pemahaman konsep yang baik. Apabila peserta didiknya tidak paham 
akan konsep dari materi yang dipelajari, maka mereka akan kesulitan dalam memecahkan masalah-masalah yang berkaitan dengan materi yang dipelajarinya.

Pemahaman konsep berdasarkan Taksonomi Bloom berada pada ranah kognitif kategori memahami C2. Pemahaman konsep ini haruslah terbentuk dalam setiap bentuk pembelajaran sehingga peserta didik dapat memperoleh hasil belajar yang baik saat ujian sesuai dengan pemahaman konsepnya (Tsabit et al., 2020), begitupun dalam pelaksanaan pembelajaran online. Oleh karena itu, analisis mengenai pemahaman konsep perlu diadakan agar dapat mengetahui sejauh mana kemampuan pemahaman konsep yang dimiliki peserta didik setelah mengikuti pembelajaran online.

Penelitian mengenai analisis kemampuan pemahaman konsep telah dilakukan oleh beberapa peneliti. Salah satu penelitian serupa yang telah dilakukan yaitu: "Analisis Pemahaman Konsep Vektor pada Siswa Sekolah Menengah Atas" . Hasil penelitian yang dilakukan (Sari, Suyanto, \& Suana, 2017) menunjukkan bahwa pemahaman konsep peserta didik kelas XI IPA di 4 SMA di Kecamatan Natar dinilai sedang, dengan persentase 39,1\% memahami konsep, $12 \%$ peserta didik hanya menebak dan 48,9\% tidak memahami konsep. Berdasarkan latar belakang di atas dan referensi penelitian yang telah dilakukan, peneliti tertarik untuk melakukan penelitian yang diberi judul "Analisis Pemahaman Konsep Fisika Peserta Didik Kelas X IPA di SMA Negeri 1 Manokwari Melalui Pembelajaran Online”.

\section{LANDASAN TEORI}

Pemahaman konsep merupakan unsur yang sangat penting dalam fisika. Pemahaman konsep sendiri terdari dari dua kata yaitu "pemahaman" dan "konsep". Pemahaman konsep adalah penguasaan sejumlah materi pembelajaran, dimana peserta didiknya tidak hanya sekedar mengetahui dan mengenal tetapi juga mampu mengungkapkan kembali konsep dengan yang lebih mudah dimengerti serta mampu mengaplikasikannya (Fajar, Kodirun, Suhar, \& Arapu, 2018). Pemahaman konsep yang baik merupakan dasar dari kemampuan pemecahan masalah yang baik (Yana et al., 2019). Menurut Bloom, pemahaman konsep berada pada ranah kognitif kategori C2 memahami dan memiliki 7 proses kognitif yaitu 1) menafsirkan, 2) mencontohkan, 3) mengklasifikasi, 4) merangkum, 5) menyimpulkan, 6) membandingkan, dan 7) menjelaskan (Tsabit et al., 2020). Pemahaman konsep yang menjadi fokus dalam penelitian ini adalah pemahaman konsep mata pelajaran fisika pada pokok bahasan hukum Newton tentang gerak lurus. 
Pembelajaran online adalah proses pembelajaran yang memanfaatkan media internet dan media elektronik sebagai sarana pembelajaran. Menurut Dabbagh dan Ritland pembelajaran online adalah sistem pembelajaran terbuka dan tersebar dengan menggunakan perangkat bantu pendidikan yang terhubung melalui teknologi berbasis jaringan dan internet guna memfasilitasi proses pembelajaran dan pengetahuan melalui aksi dan interaksi antar penggunanya (Arnesi \& Hamid, 2015). Pembelajaran online dapat dilakukan dengan menggunakan beberapa aplikasi seperti google classroom, google meet, zoom, whatsapp group, edmodo, zenius education dan lain-lain. Menurut Bates dan Wulf pembelajaran online mempunyai beberapa manfaat sebagai antara lain (1) iteraksi pembelajaran antara peserta didik dan guru semakin meningkat, (2) memungkinkan terjadinya interaksi pembelajaran dari mana dan kapan saja, (3) menjangkau peserta didik dalam cakupan yang luas, dan (4) mempermudah penyempurnaan dan penyimpanan materi pembelajaran (Waryanto, 2006).

\section{METODE PENELITIAN}

Metode penelitian yang digunakan pada penelitian ini adalah metode survey dengan menggunakan tes sebagai bahan instrumennya. Teknik pengumpulan data yang digunakan dalam penelitian ini adalah tes pemahaman konsep fisika. Peserta didik yang menjadi sampel penelitian dipilih menggunakan teknik purposive sampling. Teknik purposive sampling ini adalah teknik penentuan sampel yang dilakukan dengan pertimbangan/kriteria tertentu sesuai dengan penelitian yang dilakukan. Sampel penelitian yang diambil adalah peserta didik yang hadir pada saat KBM mata pelajaran fisika berlangsung dan telah menyelesaikan seluruh materi dengan pembelajaran yang dilakukan secara online. Tes pemahaman konsep fisika yang digunakan terdiri dari 17 pertanyaan berbetuk pilihan ganda yang disusun berdasarkan proses kognitif dari pemahaman konsep. Pertanyaan ini sudah terlebih dahulu divalidkan dan telah melalui beberapa uji item seperti uji validitas, reliabilitas, daya pembeda dan tingkat kesukaran. Uji coba instrumen tes dilakukan di kelas X IPA 2 dan X IPA 4 di SMA Negeri 1 Manokwari dengan jumlah 66 peserta didik dan jumlah pertanyaan dalam tes sebanyak 21 soal. Data dari uji coba instrumen tes digunakan untuk melakukan beberapa uji item dengan bantuan software Winsteps versi 3.73. Hasil uji validitas item menunjukkan terdapat 4 soal yang dinyatakan tidak valid. Tes pemahaman konsep dibuat dalam format google formulir (google form) dan link disebarkan kepada peserta didik dengan bantuan guru pengampu mata pelajaran fisika di kelas X IPA. Tes ini kemudian diisi oleh peserta didik dari kelas X IPA 1, 3, 5, 6, 7, 8, dan X IPA 9 di SMA Negeri 1 Manokwari dengan jumlah sampel sebanyak 219 
peserta didik. Analisis data penelitian yang digunakan dalam penelitian ini yaitu analisis dengan metode deskriptif menggunakan rumus persentase deskriptif.

$$
D p=\frac{n}{N} \times 100 \%
$$

(Trianjaya, 2012)

Keterangan:

Dp : deskriptif persentase (\%)

$n \quad$ : skor yang diperoleh

N $\quad$ : skor ideal

\section{HASIL DAN PEMBAHASAN}

Hasil persentase deskriptif menunjukkan pemahaman konsep fisika peserta didik kelas $\mathrm{X}$ IPA SMA Negeri 1 Manokwari terbagi kedalam lima kelompok kategori. Lima kategori yang didapat atara lain kategori sangat tinggi, kategori tinggi, kategori sedang, kategori rendah dan kategori sangat rendah, yang hasilnya dapat dilihat pada Gambar 1.

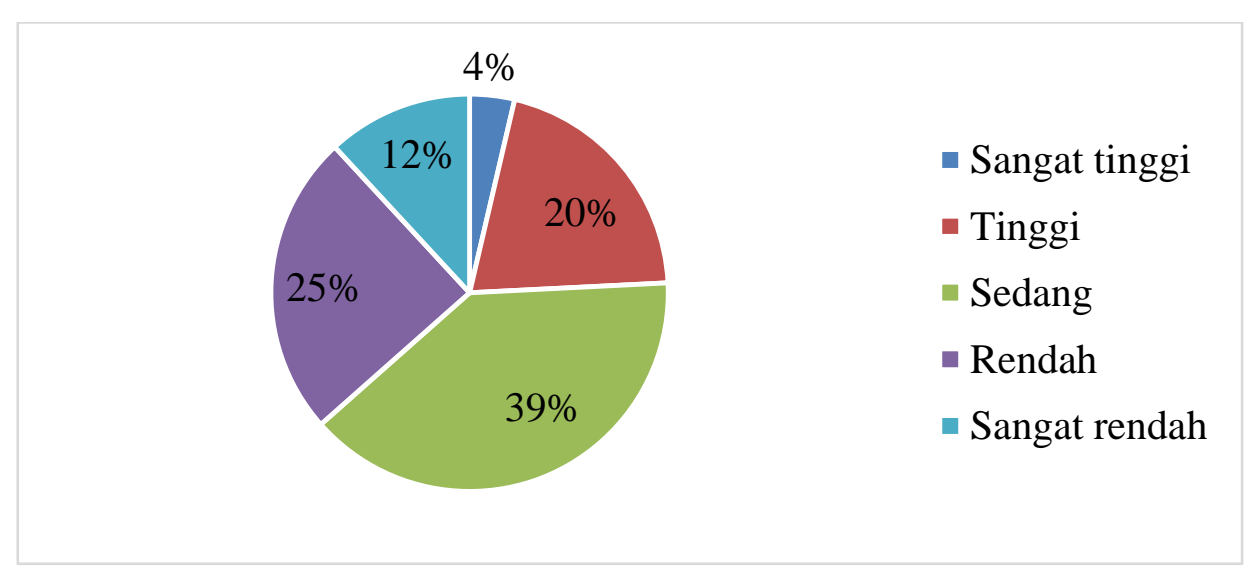

Gambar 1. Persentase deskriptif pemahaman konsep fisika keseluruhan tes

Tes pemahaman konsep fisika ini dibuat berdasarkan tujuh proses kognitif. Pemahaman konsep fisika peserta didik berdasarkan tujuh proses kognitif tersebut dapat dilihat pada Gambar 2. 


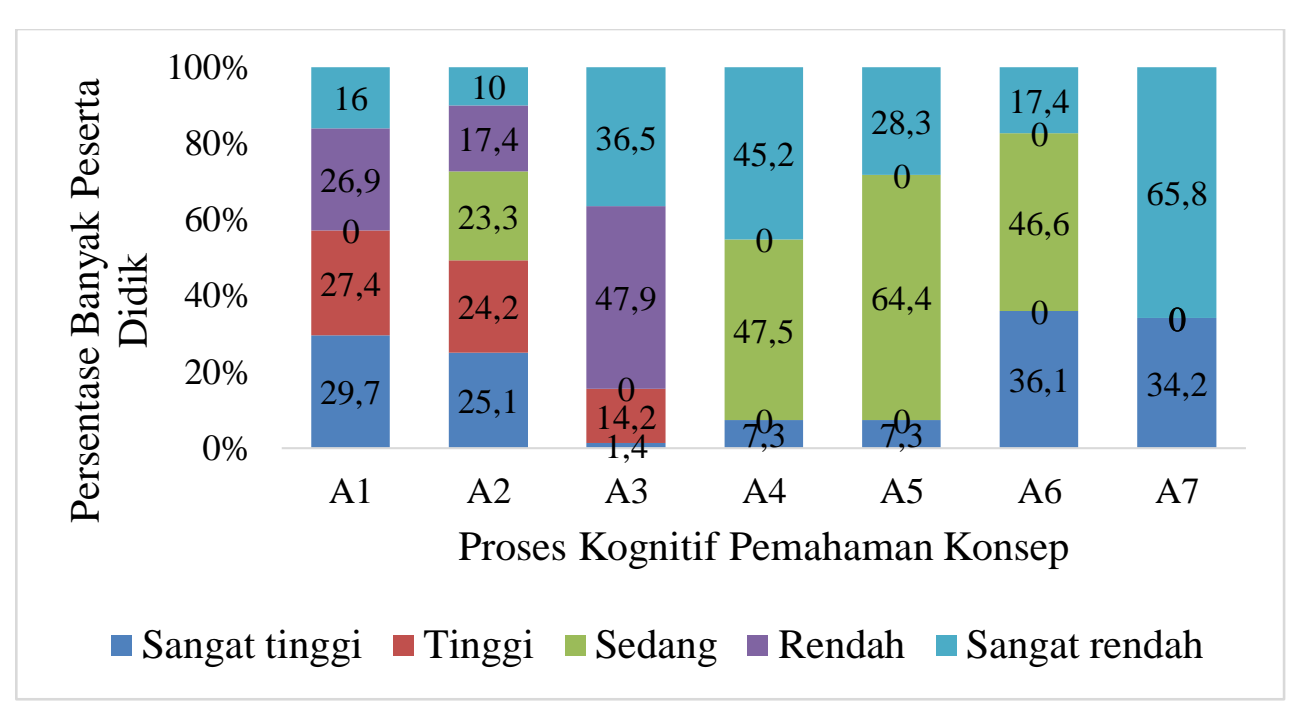

Gambar 2. Pemahaman konsep fisika berdasarkan proses kognitif

Gambar 2 memperlihatkan bagaimana tingkat pemahaman konsep fisika peserta didik dari setiap proses kognitifnya. Berdasarkan Gambar 2 tersebut diketahui beberapa hal yang telah dirangkum sebagai berikut.

Proses kognitif A1 (menafsirkan), peserta didik paling banyak memiliki kemampuan pemahaman konsep sangat tinggi dengan persentase peserta didik sebesar 29,7\%. Kemampuan sangat tinggi ini menujukkan bahwa peserta didik tersebut menjawab benar seluruh pertanyaan dari 3 pertanyaan yang tersedia. Proses A2 (mencontohkan), peserta didiknya mayoritas memiliki kemampuan pemahaman konsep sangat tinggi dengan persentase peserta didik sebesar $25,1 \%$. Kemampuan sangat tinggi ini menujukkan bahwa peserta didik tersebut menjawab benar seluruh pertanyaan dari 4 pertanyaan yang tersedia.

Peserta didik mayoritas memiliki kemampuan pemahaman konsep rendah pada proses kognitif A3 (mengklasifikasikan) dengan persentase peserta didik sebesar 47,9\%. Kemampuan rendah ini menujukkan bahwa peserta didik tersebut menjawab benar 1 pertanyaan dari 3 pertanyaan yang tersedia. Proses kogitif A4 (merangkum), A5 (menyimpulkan) dan A6 (membandingkan) peserta didik paling banyak memiliki kemampuan pemahaman konsep berkategori sedang, dengan masing-masing persentase peserta didik sebesar 47,5\%, 64,4\% dan 46,6\%. Kemampuan sedang ini menujukkan bahwa peserta didik tersebut menjawab benar 1 pertanyaan dari 2 pertanyaan yang tersedia.

Proses kognintif A7 (menjelaskan), peserta didik mayoritas memiliki kemampuan pemahaman konsep yang sangat rendah dengan persentase peserta didik sebesar $65,8 \%$. Kemampuan sangat rendah ini menujukkan bahwa peserta didik tersebut tidak menjawab 
benar semua pertanyaan yang tersedia. Pemahaman konsep fisika peserta didik disetiap proses kognitif lebih lanjutnya akan dijabarkan dan dibahas sebagai berikut.

\section{Proses Kognitif Menafsirkan (A1)}

Pertanyaan dengan proses kognitif menafsirkan dalam tes ini sebanyak 3 soal. Pertanyaan tersebut antara lain pertanyaan dengan kode soal I3, I4, dan I16. Pertanyaan dengan kode soal I3 adalah pertanyaan mengenai Hukum II Newton, dengan bunyi pertanyaan "Menurut hukum II Newton, pernyataan berikut ini yang benar adalah...".

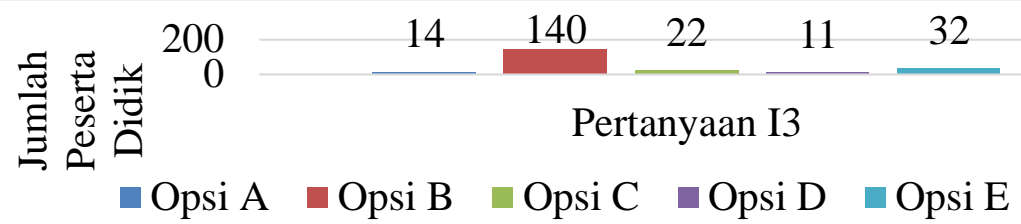

Gambar 3. Distribusi pilihan jawaban peserta didik pertanyaan I3

Pertanyaan I3 ini memiliki kunci jawaban benar yaitu opsi B. Berdasarkan Gambar 3 diketahui bahwa sebanyak 140 peserta didik memilih jawaban B sebagai jawaban yang paling benar, artinya sebanyak $63,9 \%$ peserta didiknya sudah memahami materi terkait pertanyaan I3 yang diberikan.

Pertanyaan dengan kode soal I4 berbunyi “Jika benda A memberikan gaya pada benda B, berdasarkan hukum III Newton kedua benda tersebut akan saling memberikan gaya satu sama lain dimana...".

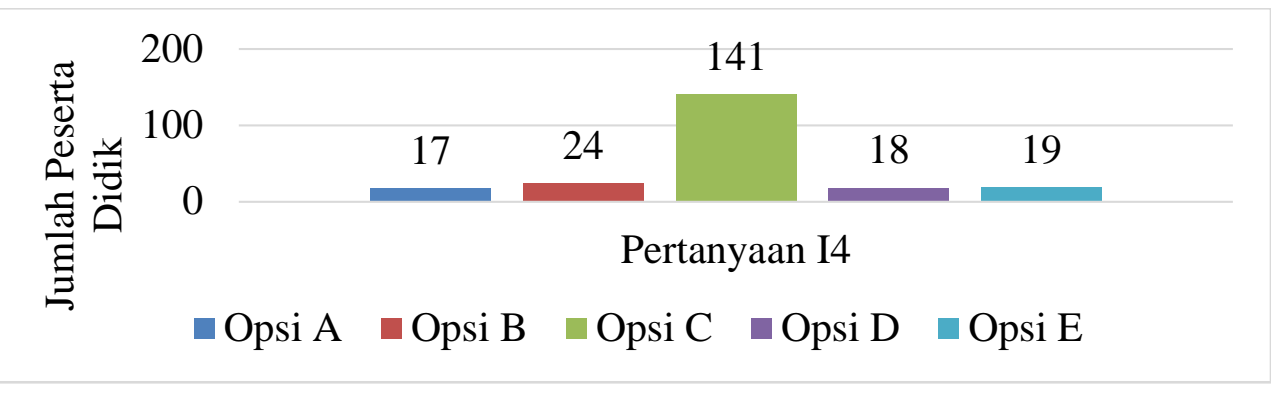

Gambar 4. Distribusi pilihan jawaban peserta didik pertanyaan I4

Pertanyaan I4 ini memiliki kunci jawaban benar yaitu opsi C. Berdasarkan Gambar 4 diketahui bahwa sebanyak 141 peserta didik memilih jawaban $\mathrm{C}$ sebagai jawaban yang paling benar, artinya sebanyak $64,4 \%$ peserta didiknya sudah memahami materi terkait pertanyaan I4 yang diberikan.

Pertanyaan dengan kode soal I16 berbunyi "Sebuah kardus diletakkan didalam lantai lift dan lift tersebut dalam keadaan turun. Kardus tersebut akan tetap diam apabila...”. 


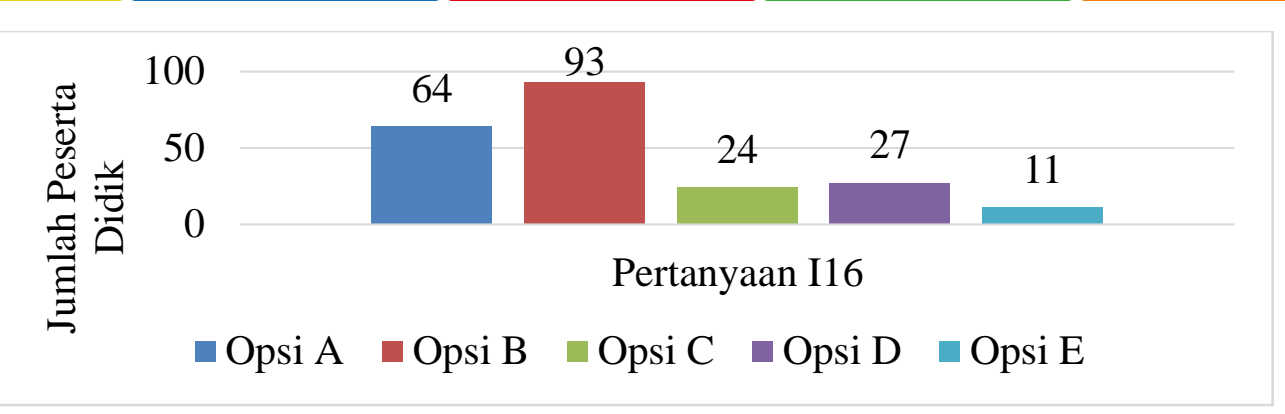

Gambar 5. Distribusi pilihan jawaban peserta didik pertanyaan I16

Pertanyaan I16 ini memiliki kunci jawaban benar yaitu opsi B. Berdasarkan Gambar 5 diketahui bahwa sebanyak 93 peserta didik memilih jawaban B sebagai jawaban yang paling benar, artinya sebanyak $42,5 \%$ peserta didiknya sudah memahami materi terkait pertanyaan I6 yang diberikan.

Berdasarkan penjabaran hasil dari setiap pertanyaan pada proses kognitif menafsirkan (A1), diketahui banyak peserta didik yang menjawab benar di setiap pertanyaan. Hasil ini menunjukkan peserta didik yang menjawab benar setiap pertanyaan memiliki kemampuan pemahaman konsep sangat tinggi, dan jika dilihat pada Gambar 2, diketahui dengan persentase peserta didik sebanyak $29,7 \%$.

\section{Proses Kognitif Mencontohkan (A2)}

Pertanyaan dengan proses kognitif mencontohkan dalam tes ini sebanyak 4 soal. Pertanyaan tersebut antara lain pertanyaan dengan kode soal I2, I5, I6, dan I11. Pertanyaan dengan kode soal I2 berbunyi "Seorang pengemudi bus mengerem kendaraannya secara tibatiba. Pada saat direm, para penumpang terdorong ke depan. Hal ini terjadi karena...”.

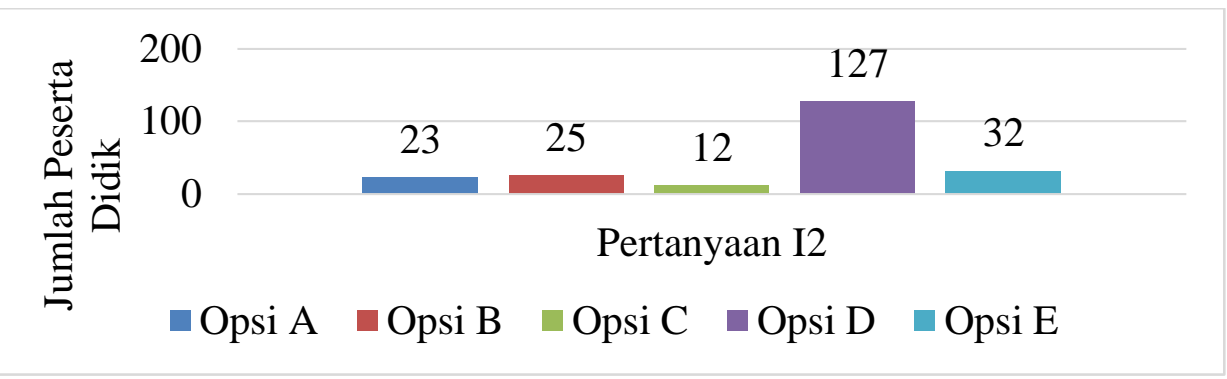

Gambar 6. Distribusi pilihan jawaban peserta didik pertanyaan I2

Pertanyaan I2 ini memiliki kunci jawaban benar yaitu opsi D. Berdasarkan Gambar 6 diketahui bahwa sebanyak 127 peserta didik memilih jawaban D sebagai jawaban yang paling benar, artinya sebanyak $58 \%$ peserta didiknya sudah memahami materi terkait pertanyaan I2 yang diberikan.

Pertanyaan dengan kode soal I5 berbunyi “Berdasarkan pernyataan di atas, kegiatan yang menunjukkan penerapan Hukum III Newton ditunjukkan oleh pernyataan nomor...". 


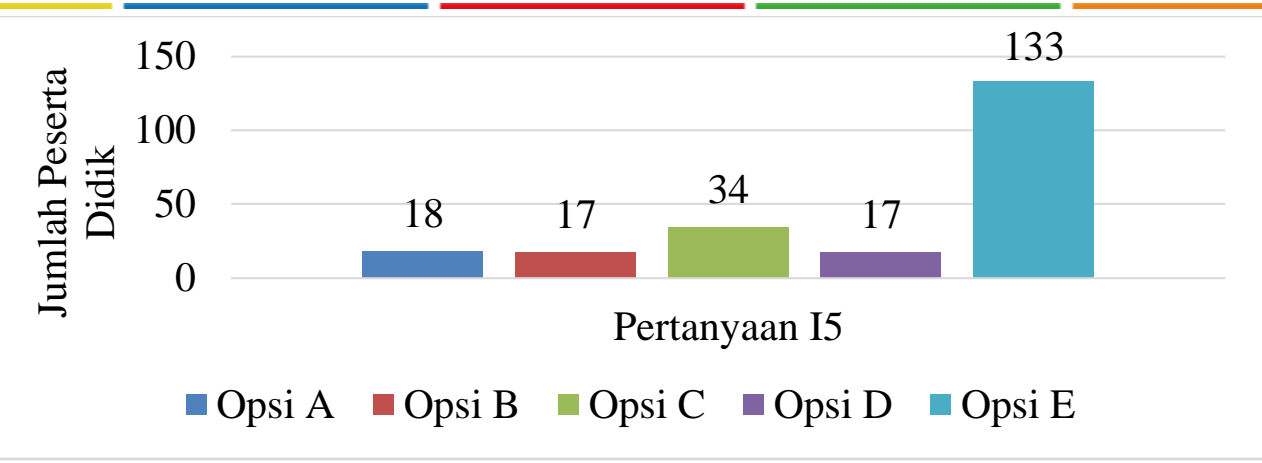

Gambar 7. Distribusi pilihan jawaban peserta didik pertanyaan I5

Pertanyaan I5 ini memiliki kunci jawaban benar yaitu opsi E. Berdasarkan Gambar 7 diketahui bahwa sebanyak 133 peserta didik memilih jawaban E sebagai jawaban yang paling benar, artinya sebanyak $60,7 \%$ peserta didiknya sudah memahami materi terkait pertanyaan I5 yang diberikan.

Pertanyaan dengan kode soal I6 berbunyi "Contoh Hukum II Newton yang benar adalah...".

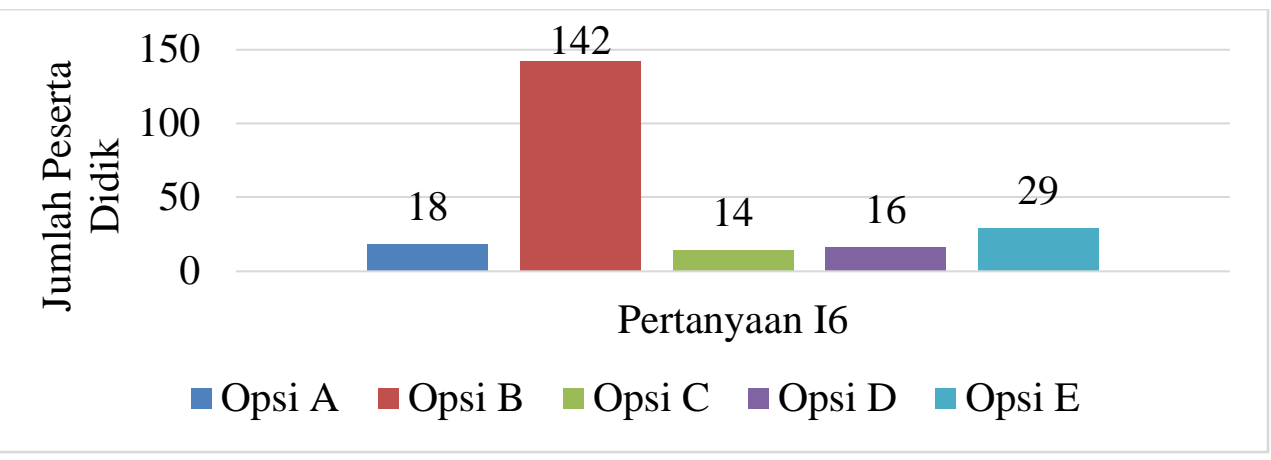

Gambar 8. Distribusi pilihan jawaban peserta didik pertanyaan I6

Pertanyaan I6 ini memiliki kunci jawaban benar yaitu opsi B. Berdasarkan Gambar 8 diketahui bahwa sebanyak 142 peserta didik memilih jawaban B sebagai jawaban yang paling benar, artinya sebanyak $64,8 \%$ peserta didiknya sudah memahami materi terkait pertanyaan I6 yang diberikan.

Pertanyaan dengan kode I11 berbunyi "Berikut ini adalah contoh gaya gesekan yang menguntungkan, kecuali...". 


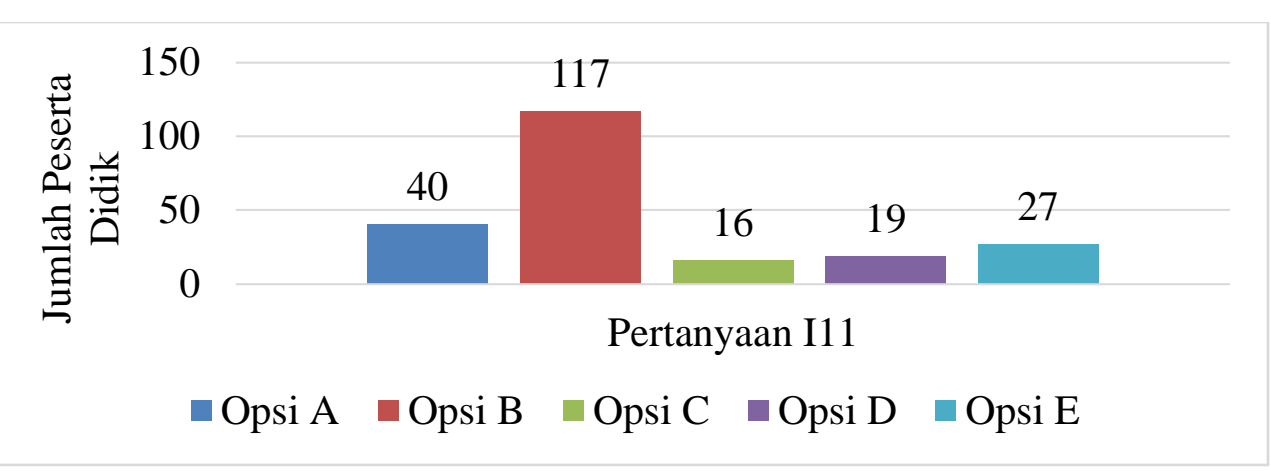

Gambar 9. Distribusi pilihan jawaban peserta didik pertanyaan I11

Pertanyaan I11 ini memiliki kunci jawaban benar yaitu opsi B. Berdasarkan Gambar 9 diketahui bahwa sebanyak 117 peserta didik memilih jawaban B sebagai jawaban yang paling benar, artinya hanya 53,4\% peserta didiknya yang sudah memahami materi terkait pertanyaan I11 yang diberikan.

Berdasarkan penjabaran hasil dari setiap pertanyaan pada proses kognitif mencontohkan (A2), diketahui banyak peserta didik yang menjawab benar di setiap pertanyaan. Hasil ini menunjukkan peserta didik yang menjawab benar setiap pertanyaan memiliki kemampuan pemahaman konsep sangat tinggi, dan jika dilihat pada Gambar 2, diketahui dengan persentase peserta didik sebanyak $25,1 \%$.

\section{Proses Kognitif Mengklasifikasikan (A3)}

Pertanyaan dengan proses kognitif mengklasifikasikan dalam tes ini sebanyak 3 soal. Pertanyaan tersebut antara lain pertanyaan dengan kode soal I12, I14, dan I17. Pertanyaan dengan kode soal 12 berbunyi "Sesuai dengan hukum gerak, diagram di bawah ini yang tepat untuk menggambarkan arah kecepatan $v$ dan percepatan sentripetal $a_{s}$ dari gerak rotasi kincir angin tersebut adalah...".

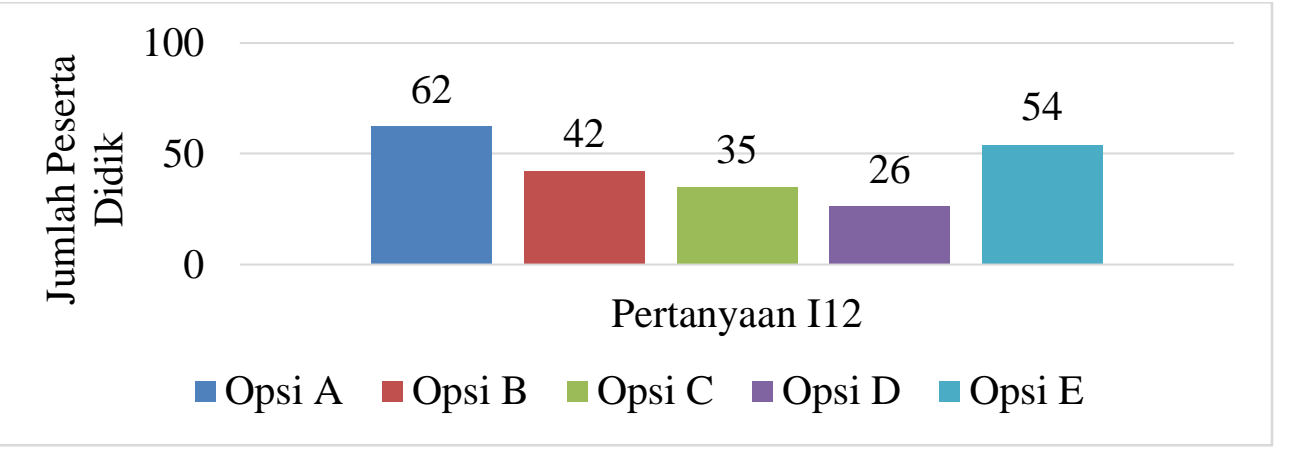

Gambar 10. Distribusi pilihan jawaban peserta didik pertanyaan I12

Pertanyaan I12 ini memiliki kunci jawaban benar yaitu opsi E. Berdasarkan Gambar 10 diketahui bahwa sebanyak 54 peserta didik memilih jawaban E sebagai jawaban yang paling Puplished at https://ojs.stkippgri-lubuklinggau.ac.id/index.php/SJPIF 
benar, artinya hanya $24,7 \%$ peserta didiknya yang sudah memahami materi terkait pertanyaan I12 yang diberikan.

Pertanyaan dengan kode soal I14 berbunyi “Gambar tersebut yang benar menunjukkan arah gaya-gaya yang bekerja adalah...”.

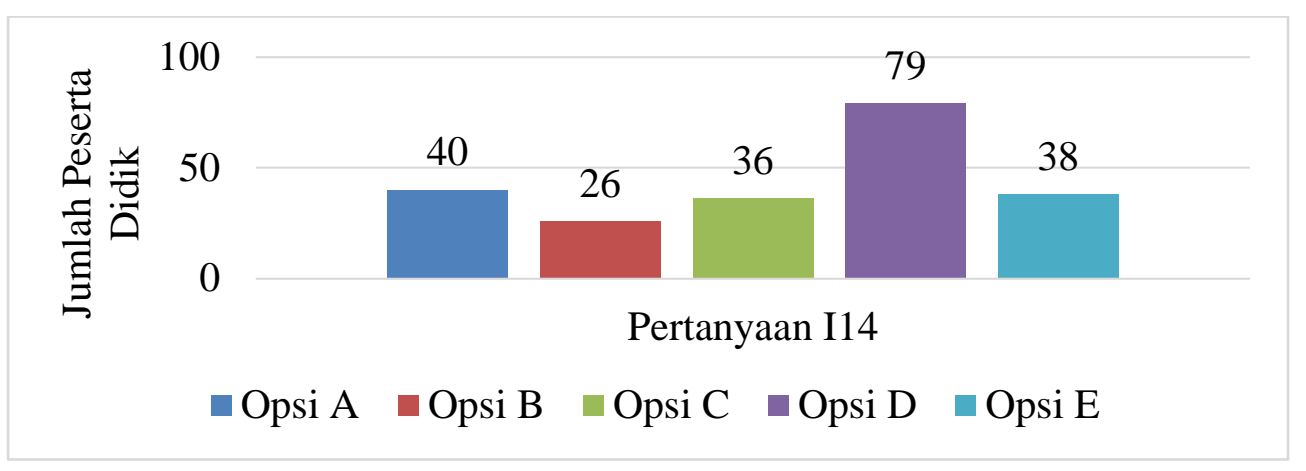

Gambar 11. Distribusi pilihan jawaban peserta didik pertanyaan I14

Pertanyaan I14 ini memiliki kunci jawaban benar yaitu opsi B. Berdasarkan Gambar 11 diketahui bahwa sebanyak 26 peserta didik memilih jawaban B sebagai jawaban yang paling benar, artinya hanya $11,9 \%$ peserta didiknya yang sudah memahami materi terkait pertanyaan I14 yang diberikan.

Pertanyaan dengan kode I17 berbunyi "Besar gaya gesekan yang bekerja pada benda yang bergerak pada bidang miring kasar jika gaya gesekan dengan udara diabaikan bergantung pada...".

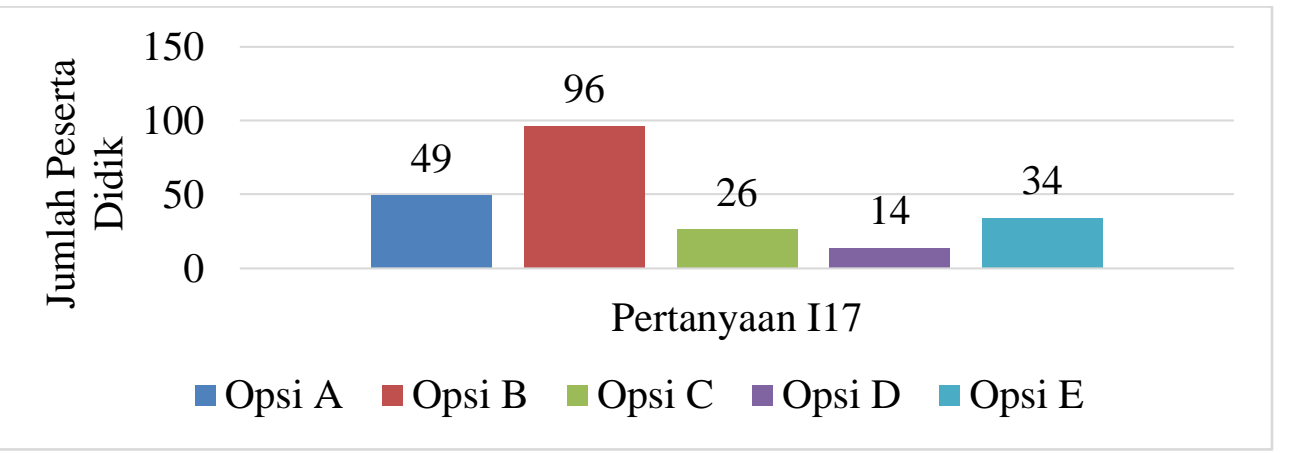

Gambar 12. Distribusi pilihan jawaban peserta didik pertanyaan I17

Pertanyaan I17 ini memiliki kunci jawaban benar yaitu opsi B. Berdasarkan Gambar 12 diketahui bahwa sebanyak 96 peserta didik memilih jawaban B sebagai jawaban yang paling benar, artinya sebanyak $43,8 \%$ peserta didiknya sudah memahami materi terkait pertanyaan I17 yang diberikan.

Berdasarkan penjabaran hasil dari setiap pertanyaan pada proses kognitif mengklasifikasikan (A3), diketahui sebagian peserta didik yang kemungkinan menjawab benar 1 dari 3 pertanyaan yang ada. Hasil ini menunjukkan peserta didik yang menjawab Puplished at https://ojs.stkippgri-lubuklinggau.ac.id/index.php/SJPIF 
benar 1 pertanyaan tersebut memiliki kemampuan pemahaman konsep rendah, dan jika dilihat pada Gambar 2, diketahui dengan persentase peserta didik sebanyak 47,9\%.

\section{Proses Kognitif Merangkum (A4)}

Pertanyaan dengan proses kognitif merangkum dalam tes ini sebanyak 2 soal. Pertanyaan tersebut antara lain pertanyaan dengan kode soal I15, dan I18. Pertanyaan dengan kode soal I15 berbunyi "Selama sebuah benda bergerak dalam bidang yang kasar, gaya normal dan gaya gesekan yang dialami benda tersebut yaitu...".

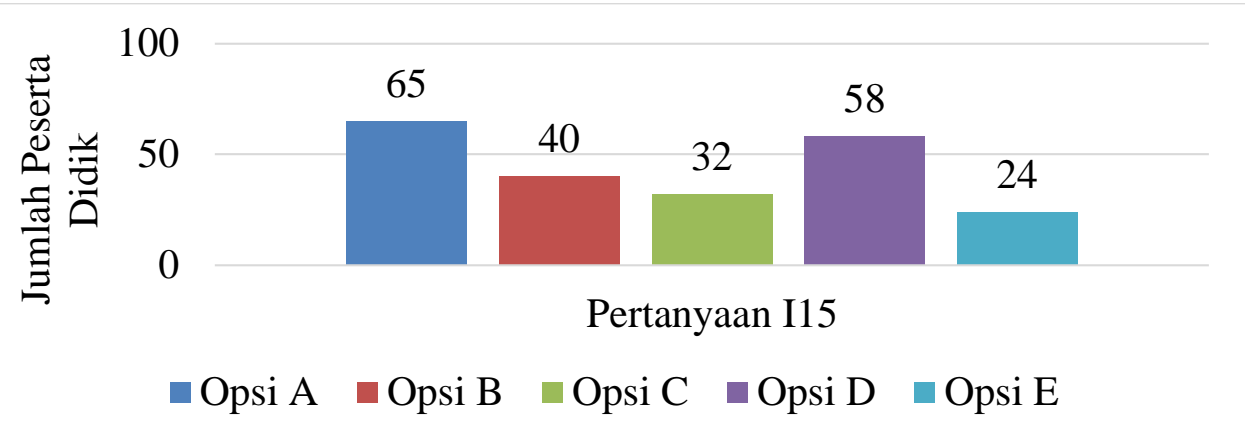

Gambar 13. Distribusi pilihan jawaban peserta didik pertanyaan I15

Pertanyaan I15 ini memiliki kunci jawaban benar yaitu opsi C. Berdasarkan Gambar 13 diketahui bahwa sebanyak 96 peserta didik memilih jawaban $\mathrm{C}$ sebagai jawaban yang paling benar, artinya hanya $14,6 \%$ peserta didiknya yang sudah memahami materi terkait pertanyaan I15 yang diberikan.

Pertanyaan dengan kode soal I18 berbunyi "Opsi di bawah ini yang benar mengenai rangkuman hubungan antara besar nilai gaya normal $N$ dan berat $w$ seseorang saat berada di dalam lift adalah...".

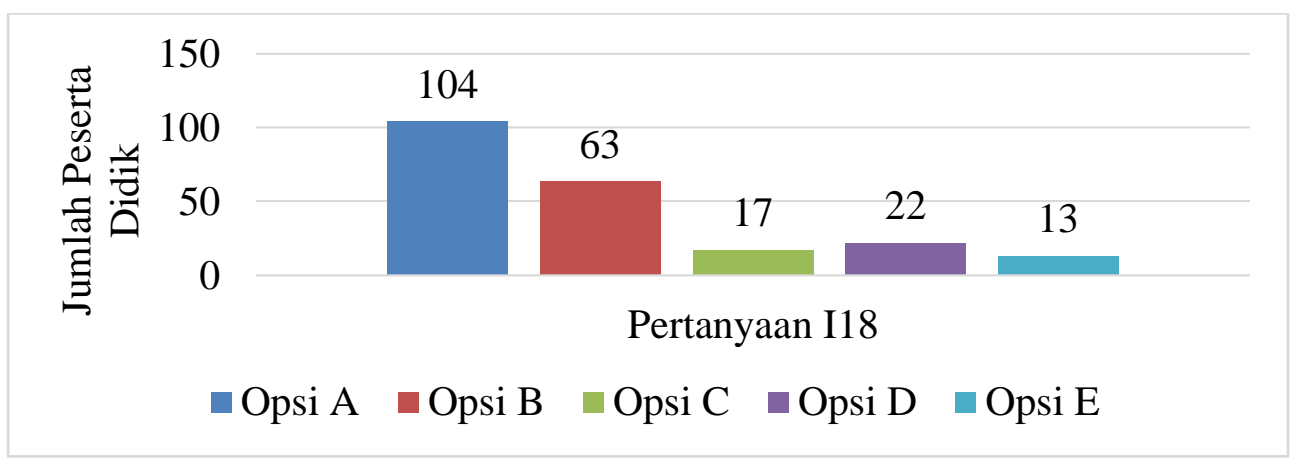

Gambar 14. Distribusi pilihan jawaban peserta didik pertanyaan I18

Pertanyaan I18 ini memiliki kunci jawaban benar yaitu opsi A. Berdasarkan Gambar 14 diketahui bahwa sebanyak 104 peserta didik memilih jawaban A sebagai jawaban yang paling 
benar, artinya sebanyak 47,5\% peserta didiknya sudah memahami materi terkait pertanyaan I18 yang diberikan.

Berdasarkan penjabaran hasil dari setiap pertanyaan pada proses kognitif merangkum (A4), diketahui banyak peserta didik yang kemungkinan menjawab benar 1 dari 2 pertanyaan yang ada. Hasil ini menunjukkan peserta didik yang menjawab benar 1 pertanyaan tersebut memiliki kemampuan pemahaman konsep sedang, dan jika dilihat pada Gambar 2, diketahui dengan persentase peserta didik sebanyak 47,5\%.

\section{Proses Kognitif Menyimpulkan (A5)}

Pertanyaan dengan proses kognitif menyimpulkan dalam tes ini sebanyak 2 soal. Pertanyaan tersebut antara lain pertanyaan dengan kode soal I7, dan I19. Pertanyaan dengan kode soal 17 berbunyi "Sebuah benda yang dikenai gaya dapat bergerak dengan kecepatan konstan $v$, sehingga besar gaya total yang bekerja pada benda tersebut adalah...”.

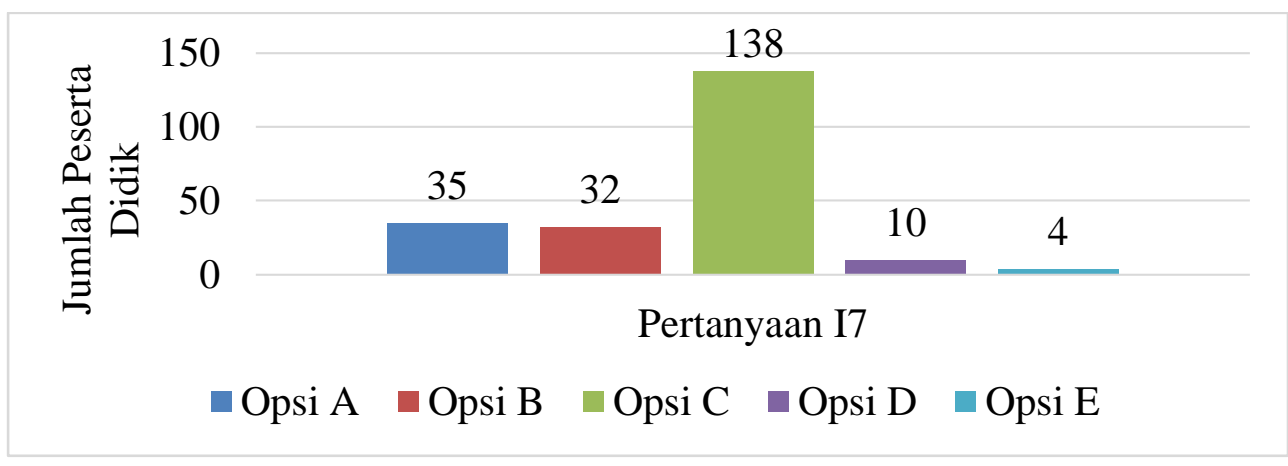

Gambar 15. Distribusi pilihan jawaban peserta didik pertanyaan I7

Pertanyaan I7 ini memiliki kunci jawaban benar yaitu opsi C. Berdasarkan Gambar 15 diketahui bahwa sebanyak 138 peserta didik memilih jawaban $\mathrm{C}$ sebagai jawaban yang paling benar, artinya sebanyak $63 \%$ peserta didiknya sudah memahami materi terkait pertanyaan I7 yang diberikan.

Pertanyaan dengan kode soal I19 berbunyi "Sebuah benda diam yang berada pada bidang miring berusaha ditarik ke atas mobil menggunakan sebuah tali. Karena . . . menyebabkan benda tersebut masih tetap belum bergerak.". 


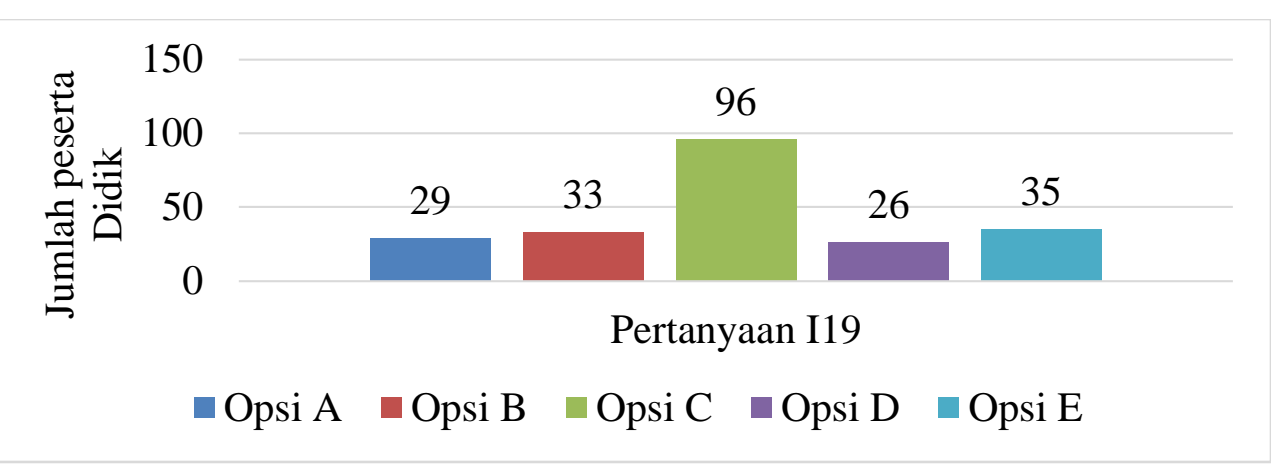

Gambar 16. Distribusi pilihan jawaban peserta didik pertanyaan I19

Pertanyaan I19 ini memiliki kunci jawaban benar yaitu opsi E. Berdasarkan Gambar 16 diketahui bahwa sebanyak 35 peserta didik memilih jawaban E sebagai jawaban yang paling benar, artinya hanya $16 \%$ peserta didiknya yang sudah memahami materi terkait pertanyaan I19 yang diberikan.

Berdasarkan penjabaran hasil dari setiap pertanyaan pada proses kognitif menyimpulkan (A5), diketahui sebagian besar peserta didik yang kemungkinan menjawab benar 1 dari 2 pertanyaan yang ada. Hasil ini menunjukkan dominan peserta didik yang menjawab benar 1 pertanyaan tersebut memiliki kemampuan pemahaman konsep sedang, dan jika dilihat pada Gambar 2, diketahui dengan persentase peserta didik sebanyak 64,4\%.

\section{Proses Kognitif Membandingkan (A6)}

Pertanyaan dengan proses kognitif membandingkan dalam tes ini sebanyak 2 soal. Pertanyaan tersebut antara lain pertanyaan dengan kode soal I8, dan I10. Pertanyaan dengan kode soal I8 berbunyi "Benda A dan B terletak di atas lantai licin. Massa benda A tiga kali massa benda B. Jika pada kedua benda bekerja gaya mendatar yang sama, maka perbandingan percepatan antara benda A dan benda B adalah...".

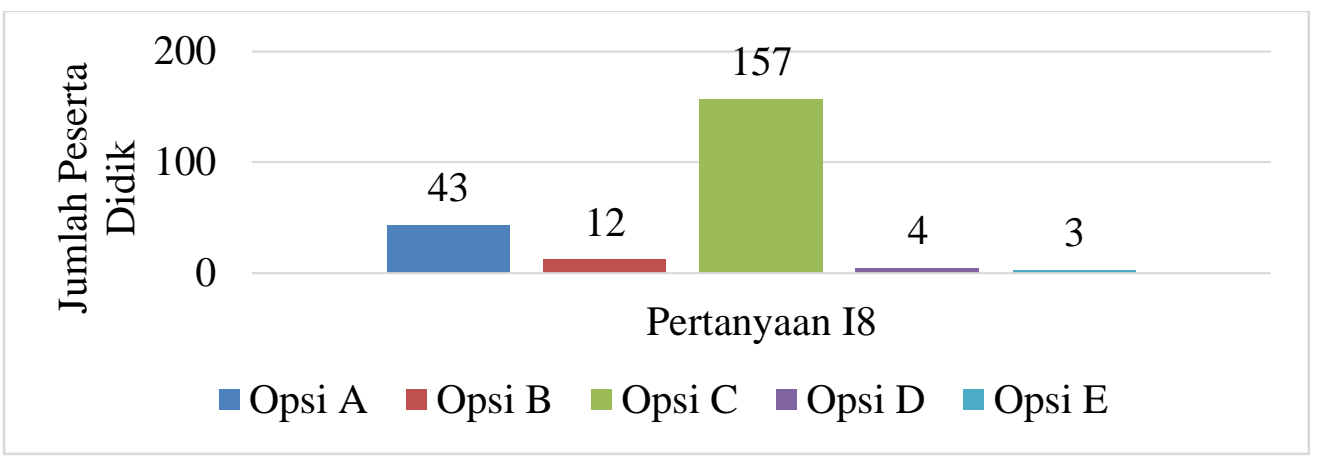

Gambar 17. Distribusi pilihan jawaban peserta didik pertanyaan I8

Pertanyaan I8 ini memiliki kunci jawaban benar yaitu opsi C. Berdasarkan Gambar 17 diketahui bahwa sebanyak 157 peserta didik memilih jawaban $\mathrm{C}$ sebagai jawaban yang paling Puplished at https://ojs.stkippgri-lubuklinggau.ac.id/index.php/SJPIF 
benar, artinya sebanyak $71,7 \%$ peserta didiknya sudah memahami materi terkait pertanyaan I8 yang diberikan.

Pertanyaan dengan kode soal I10 berbunyi "Gambar yang akan memberikan percepatan terbesar pada balok bermassa M di tunjukkan oleh...".

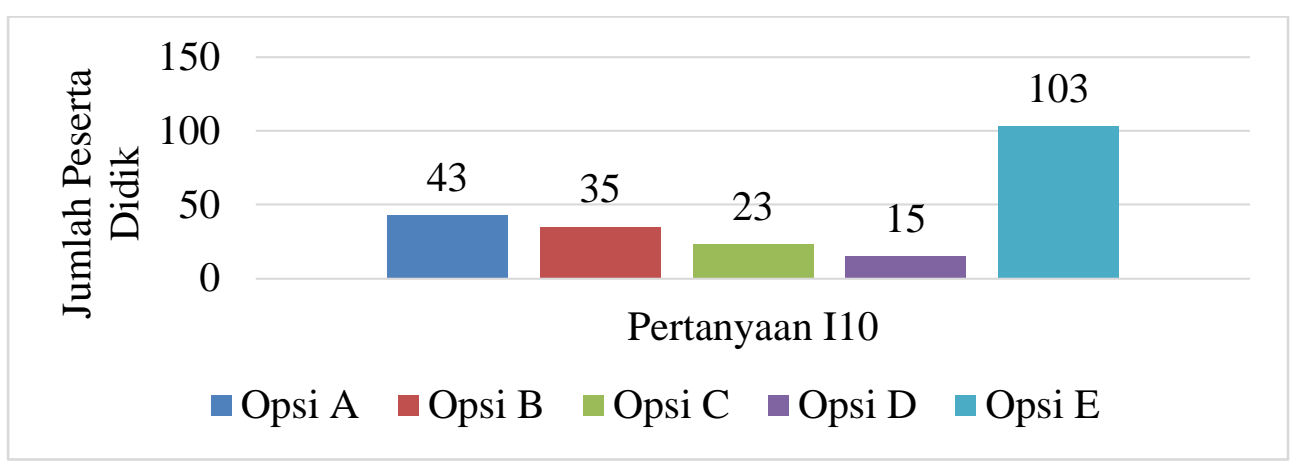

Gambar 18. Distribusi pilihan jawaban peserta didik pertanyaan I10

Pertanyaan I10 ini memiliki kunci jawaban benar yaitu opsi E. Berdasarkan Gambar 18 diketahui bahwa sebanyak 103 peserta didik memilih jawaban E sebagai jawaban yang paling benar, artinya sebanyak $47 \%$ peserta didiknya sudah memahami materi terkait pertanyaan I10 yang diberikan.

Berdasarkan penjabaran hasil dari setiap pertanyaan pada proses kognitif membandingkan (A6), diketahui banyak peserta didik yang kemungkinan menjawab benar 1 dari 2 pertanyaan yang ada. Hasil ini menunjukkan peserta didik yang menjawab benar 1 pertanyaan tersebut memiliki kemampuan pemahaman konsep sedang, dan jika dilihat pada Gambar 5.3, diketahui dengan persentase peserta didik sebanyak 46,6\%.

\section{Proses Kognitif Menjelaskan (A7)}

Pertanyaan dengan proses kognitif menjelaskan dalam tes ini sebanyak 1 soal. Pertanyaan adalah pertanyaan dengan kode soal I9, yang berbunyi "Gaya yang mengenai benda diam menyebabkan benda bergerak. Gaya yang mengenai benda bergerak dapat menyebabkan benda...".

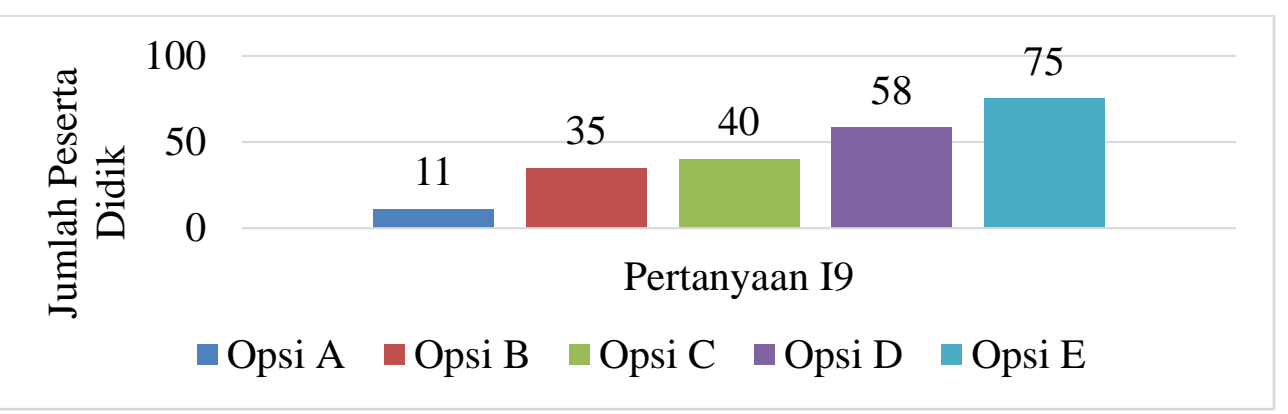

Gambar 19. Distribusi pilihan jawaban peserta didik pertanyaan I9 
Pertanyaan I9 ini memiliki kunci jawaban benar yaitu opsi E. Berdasarkan Gambar19 diketahui bahwa sebanyak 75 peserta didik memilih jawaban E sebagai jawaban yang paling benar, artinya sebanyak $34,2 \%$ peserta didiknya sudah memahami materi terkait pertanyaan I9 yang diberikan.

Berdasarkan penjabaran hasil dari pertanyaan pada proses kognitif menjelaskan (A7), diketahui sebagian besar peserta didik yang kemungkinan menjawab salah dari 1 pertanyaan yang diberikan. Hasil ini menunjukkan dominan peserta didik yang menjawab salah pertanyaan tersebut memiliki kemampuan pemahaman konsep sangat rendah, dan jika dilihat pada Gambar 2, diketahui dengan persentase peserta didik sebanyak 65,8\%.

Pertanyaan-pertanyaan pemahaman konsep berdasarkan proses kognitif diatas dianggap sudah mewakili pertanyaan pemahaman konsep secara keseluruhan. Penelitian yang serupa dilakukan oleh Tsabit et al. (2020), dimana pertanyaan di dalam tes yang dijadikan instrumen penelitiannya dibuat dan disusun berdasarkan proses kognitif dari pemahaman konsep. Tsabit dan kawan-kawan juga menganalisis pemahaman konsep peserta didiknya tidak hanya secara keseluruhan, namun juga menganalisisnya berdasarkan proses kognitifnya.

\section{SIMPULAN DAN SARAN}

Berdasarkan hasil temuan dan pembahasan, peneliti dapat menyimpulkan bahwa pemahaman konsep fisika peserta didik kelas X IPA SMA Negeri 1 Manokwari melalui pembelajaran online pada materi hukum Newton tentang gerak lurus terbagi dalam lima kategori. Kategori pencapaian pemahaman konsep fisika yang dimaksud antara lain (1) kategori sangat tinggi sebesar 4\%, (2) kategori tinggi sebesar 20\%, (3) kategori sedang sebesar 39\%, (4) kategori rendah sebesar 25\% dan (5) kategori sangat rendah sebesar $12 \%$. Persentase pencapaian pemahaman konsep fisika ini didapat dengan menggunakan instrumen tes yang telah valid dengan total pertanyaan sebanyak 17 soal. Pemahaman konsep fisika yang paling terlihat adalah pada proses kognitif menafsirkan dengan persentase peserta didik berkemampuan sangat tinggi dan tinggi dengan jumlah total 57,1\% peserta didik.

Berdasarkan hasil penelitian, peneliti memberikan saran kepada beberapa pihak sebagai berikut.

1. Bagi peserta didik, tingkatkanlah pemahaman konsep fisika dalam semua materi fisika yang dilakukan secara online ataupun secara offline serta rajin-rajinlah mengikuti pembelajaran yang dilakukan agar tidak ketinggalan materi. 
2. Bagi Guru, ada baiknya lebih memotivasi peserta didik untuk lebih rajin hadir di setiap pertemuan pada pelajaran fisika. Perbanyak memberikan pemahaman lebih mengenai materi yang dipelajari. Guru juga harus lebih kritis dalam memilih metode pembelajaran dengan tepat agar materi yang ingin disampaikan dapat diterima dan dipahami dengan baik oleh peserta didik.

3. Bagi peneliti atau calon peneliti lain, penelitian ini dapat digunakan sebagai sumber referesi dan juga pertimbangan untuk penelitian serupa yang akan dilakukan kedepanya agar kesalahan atau kekurangan dalam penelitian ini tidak terulang dikemudian hari.

\section{DAFTAR PUSTAKA}

Arnesi, N., \& Hamid, A. (2015). Penggunaan Media Pembelajaran Online-Offline dan Komunikasi Interpersonal Terhadap Hasil Belajar Bahasa Inggris. Jurnal Teknologi Informasi \& Komunikasi Dalam Pendidikan, 2(1).

Apriyani, N., Ariani, T., \& Arini, W. (2020). Pengembangan Modul Fisika Berbasis

Discovery Learning pada Materi Fluida Statis Siswa Kelas XI SMA Negeri 1 Lubuklinggau Tahun Pelajaran 2019/2020. Silampari Jurnal Pendidikan Ilmu Fisika, 2(1), 41-54.

Azizah, Z., Taqwa, M. R. A., \& Assalam, I. T. (2020). Analisis Pemahaman Konsep Fisika Peserta Didik Menggunakan Instrumen Berbantukan Quizizz. Edu Sains: Jurnal Pendidikan Sains dan Matematika, 8(2), 1-11.

Depdiknas. 2003. Undang-Undang No. 20 Bab 1 Pasal 1 Ayat 1. Undang-Undang Republik

Indonesia Nomor 20 Tahun 2003 Tentang Sistem Pendidikan Nasional. Jakarta: Departemen Pendidikan Nasional.

Dewi, W. A. F. (2020). Dampak COVID-19 terhadap Implementasi Pembelajaran Daring di Sekolah Dasar. Edukatif: Jurnal Ilmu Pendidikan, 2(1), 55-61.

Fajar, A. P., Kodirun, Suhar, \& Arapu, L. (2018). Analisis Kemampuan Pemahaman Konsep Matematis Siswa Kelas VIII SMP Negeri 17 Kendari. Jurnal Pendidikan Matematika, 9(2), 229-239.

Hermawanto, Kusairi, S., \& Wartono. (2013). Pengaruh Blended Learning terhadap Penguasaan Konsep dan Penalaran Fisika Peserta Didik Kelas X. Jurnal Pendidikan Fisika Indonesia, 9(57), 67-76.

Irwandani, \& Rofiah, S. (2015). Pengaruh Model Pembelajaran Generatif Terhadap Pemahaman Konsep Fisika Pokok Bahasan Bunyi Peserta Didik MTS Al-Hikmah 
Bandar Lampung. Jurnal Ilmiah Pendidikan Fisika Al-BiRuNi, 04(2), 165-177.

Purwanto, A., Pramono, R., Asbari, M., Santoso, P. B., Wijayanti, L. M., Chi Hyun, C., \&

Putri, R. S. (2020). Studi Eksploratif Dampak Pandemi COVID-19 Terhadap Proses

Pembelajaran Studi Eksploratif Dampak Pandemi COVID-19 Terhadap Proses

Pembelajaran Online di Sekolah Dasar. Journal of Education, Psychology and Counseling.

Sari, W. P., Suyanto, E., \& Suana, W. (2017). Analisis Pemahaman Konsep Vektor pada Siswa Sekolah Menengah Atas. Jurnal Ilmiah Pendidikan Fisika Al-BiRuNi, 06(2), 159168.

Setiawan, A. R. (2020). Lembar Kegiatan Literasi Saintifik untuk Pembelajaran Jarak Jauh Topik Penyakit Coronavirus 2019 (Covid-19). Edukatif: Jurnal Ilmu Pendidikan, 2(1), $28-36$.

Tsabit, D., Amalia, A. R., \& Maulana, L. H. (2020). Analisis Pemahaman Konsep IPS Materi Kegiatan Ekonomi Menggunakan Video Pembelajaran IPS Sistem Daring di Kelas VI.3 SDN Pakujajar CBM. Jurnal Ilmiah Pendidikan Dasar, V(1).

Waryanto, N. H. (2006). On-line Learning Sebagai Salah Satu Inovasi Pembelajaran. Pythagoras: Jurnal Matematika Dan Pendidikan Matematika, 2(1), 10-23.

Yana, A. U., Antasari, L., \& Kurniawan, B. R. (2019). Analisis Pemahaman Konsep Gelombang Mekanik Melalui Aplikasi Online Quizizz. Jurnal Pendidikan Sains Indonesia, 7(2017), 143-152.

Yunita, \& Nana. (2020). Pengunaan Model Pembelajaran POE2WE dengan Bantuan aplikasi Zenius Education untuk Meningkatkan Pemahaman Konsep dalam Pembelajaran Fisika. 